Child poverty and child rights meet active citizenship: A New Zealand and Sweden case study

\title{
Michael O'Brien
}

Massey University and Auckland University, New Zealand

\section{Tapio Salonen}

Linnaeus University and Malmo University, Sweden

\begin{abstract}
Children's rights and active citizenship have been significant policy emphases and developments in recent years but the relationship between the two has not been actively explored in relation to the implications for child poverty. Recent policy developments in New Zealand and Sweden are drawn on here to explore this relationship. The article argues that an emphasis on active citizenship does not lead to improvement of rights for all children. Too many children are left in poverty because active citizenship is focused on the lives of adults, not the needs and rights of children. Advancing children's rights requires attention to the position of all children, not just those who live in households where the adults meet active citizenship requirements.
\end{abstract}

\section{Keywords}

active citizenship, child poverty, children's rights, New Zealand, Sweden

\section{Introduction}

A focus on the rights of children and policy shifts towards 'active citizenship' have simultaneously been significant features of social policies in the new millennium, and, in the case of children's rights, long before the turn of the century. They are policies with quite different orientations towards and outcomes for children living in poverty, but the two emphases have not been critically considered together, either in policy developments or in the academic literature. In this article we analyse these divergent policies together, focusing particularly on the consequences for children living in poverty, especially those

\section{Corresponding author:}

Michael O’Brien, Massey University, Private Bag 102904, North Shore MSC,Auckland I032, New Zealand.

Email:m.a.obrien@massey.ac.nz 
children in families dependent on means-tested benefits. The focus on the needs of adults that is inherent in active citizenship works against an emphasis that all children have rights, irrespective of their carers' financial position, and is a crucial factor in the current rates of child poverty, rates which are increasing in many developed countries. This is clearly the case in both New Zealand and Sweden, the two countries which in this article serve as illustrative examples of an international trend emphasizing increased child rights at the same time as implementing and enforcing active citizenship and activation policies for the parents. Active citizenship policies do not automatically and universally lead to child poverty. However, as we demonstrate, child poverty is clearly a consequence of such policies when they are applied selectively to particular groups of children, with significant consequences for those children who remain in poverty or are kept in poverty because of the general and specific policy measures arising from active citizenship policies.

New Zealand and Sweden provide useful case studies because of the changes which have occurred in those countries' policies affecting children and because in both countries there is a significant focus on children's rights. Consistently, Sweden has served as a role model for a welfare state regime with extensive and universal ambitions in welfare and security. By international standards, Sweden has undoubtedly reached relatively high levels of citizen-related benefits and rights, but this does not mean that these aspirations to universalism apply in all situations or for all groups (Salonen, 2009a). In this case Sweden serves as an example that welfare states with fairly low child poverty could also face problems in fulfilling enlarged commitments to child rights issues in a period of rising unemployment and growing inequality. When it comes to activation policies for unemployed people, Sweden has also seen a lucid policy shift since the beginning of the 1990s from a more uniform labour market policy towards a two-tiered system where uninsured, unemployed persons are referred to secondary activation measures especially designed for people with means-tested benefits (Johansson and Möller, 2009; Salonen and Ulmestig, 2004; Ulmestig, 2007).

While not as extensive as the Swedish welfare state, New Zealand has long prided itself on its welfare provisions, with varying degrees of justification (Belgrave, 2004). However, its welfare state has undergone radical changes in the last two decades, making whatever historical claims were justified unsustainable over this period (Cheyne et al., 2008). The changes resulting from neoliberalism have also led to growing rates of poverty, especially among children in households reliant on government financial assistance (O'Brien, 2008). An activation-focused approach has dominated the case management of those receiving means-tested benefits.

The article begins with a brief discussion of children's rights, drawing on the United Nations Convention on the Rights of the Child (UNCRC). Drawing on examples from New Zealand and Sweden, we then move to a discussion on the development of active citizenship and activation policies, examining both broad policies and policies with a specific (or targeted) focus on families living on means-tested assistance, concentrating particularly on the implications for child poverty and children's rights. We conclude with a discussion of the outcomes of the ambiguous policy directions and the implications for policy and research in relation to child rights, child poverty and changes in citizenship. 


\section{The idea and development of the rights of the child}

Drawing on the 1989 UNCRC, academic researchers, child advocates and commentators on children's issues have vigorously and consistently argued that the rights of children can be broadly categorized into three areas, namely provision, protection and participation (Hallett and Prout, 2003; James et al., 1998; Mayall, 2002; Qvortrup, 2005; Tisdall, 2006).

A range of Articles in the Convention touch on issues of income adequacy, poverty and social security as these affect children, especially Articles 4, 26 and 27. ${ }^{1}$ The rights of children include a right to an adequate standard of living, explicitly set out in Clause 1 of Article 27: 'States Parties recognize the right of every child to a standard of living adequate for the child's physical, mental, spiritual, moral and social development.' While acknowledging the role of families in providing for children, the Convention goes on to place responsibility on states to meet this obligation, stating in Clause 3 of the same Article: 'States Parties, in accordance with national conditions and within their means, shall take appropriate measures to assist parents and others responsible for the child to implement this right.' Given the level of economic development of the two countries of interest here, it cannot be argued that it is not within Sweden's and New Zealand's means or inconsistent with national conditions to ensure that this right is met.

In the academic, research and advocacy work on children's rights, much emphasis has been given to the rights of children to participate in decisions which affect their lives. The focus has been on children's participation in a range of areas that affect those daily lives such as transport, recreational facilities, health and education, to give specific examples. Significantly, however, the children's rights literature has given only limited attention to issues of child poverty. For example, a recent publication on children and citizenship devotes sections to children's experiences of participation and to the law and children, but child poverty receives only passing mention (Invernizzi and Williams, 2008). ${ }^{2}$ A review of three major journals devoted to childhood studies and children's rights found a comparatively small number of articles which explored children's poverty as a children's rights issue. ${ }^{3}$ Certainly, there were articles on child poverty as experienced in developing and developed countries, but only a very limited range of literature which actively linked a discussion of child poverty and children's rights.

There are, of course, exceptions to the generalization that the linkages between children's rights and child poverty (and the impact of the latter on the former) have been largely neglected in the literature (Howe and Covell, 2003; Lister, 2004a; Pardeck, 2006; Van Bueren, 1999). Ridge (2006) provides probably the most extensive and thorough discussion of the ways in which poverty affects children's participation. Her discussion of the ways in which poverty affects participation in social and leisure activities, educational opportunities and outcomes and in social networks and friendships provides good examples of the links between poverty and reduced participation. Bradshaw et al. (2007) develop similar arguments in their comprehensive overview of conceptual and empirical work on child well-being and child poverty.

As Clutton (2008) notes, children in poor households are at a disadvantage in pursuing citizenship rights 'by proxy' through the adults in these households, because these adults have reduced resources to pursue citizenship rights. Lister (2007b: 705) captures 
this link between child poverty and children's rights neatly when she argues that while UNCRC rights provide a resource for citizenship, it is a right: 'which is jeopardized by poverty and marginalizing social divisions'.

Furthermore, children, she argues, are treated as a future investment, the result of which is that the significance of their current experiences, especially experiences of poverty, are downplayed. Poverty is important in the day-to-day current lives of children, not because they are 'citizen-worker-in-becoming or citizen-worker of the future' (Lister, 2003: 433; emphasis in original; see also Lister, 2004b). The focus on children's futures leads to neglect of the significance of the impact of children's current experiences of poverty. Poverty matters because of 'the better lives that children will lead as children' (Prout, 2000: 305). These 'better lives' are important in enabling children to exercise rights effectively. Reflecting elements of active citizenship (without using that language), Prout, echoing Lister's comment above, argues that the increasing emphasis on family responsibility means that the inequalities which are evident in the lives of parents then become equally strongly reflected in the lives and opportunities facing children.

The UNCRC sets out a framework for establishing and developing a range of policies and practices which strengthen children's rights. Implementation and academic debate has focused heavily on their right to participate, with much less attention to the ways in which poverty is linked with that participation. Alongside the attention to children's rights, policies have also emphasized the development of active citizens and it is that development to which we now turn.

\section{Active citizenship and activation}

Much of the academic work on the concept of citizenship takes TH Marshall's work as a starting point, even if the more recent academic work challenges, extends and refines his work in significant ways. (For a useful discussion of many of the current debates surrounding citizenship, see Dwyer, 2004; Hvinden and Johansson, 2007; Lewis and Surender, 2004; Lister, 1997, 2004a, 2007a, 2007b; Oliver and Barnes, 1998). Citizenship, Marshall argued, involves a comprehensive set of rights: 'from the right to a modicum of economic welfare and security to the right to share to the full in the social heritage and to live the life of a civilized being according to the standards prevailing in society' (quoted in Andersen and Jensen, 2002: 6). In brief, Marshall identified three dimensions in his seminal work on citizenship, namely civil, political and social citizenship, the last being our focus here. 'Social citizenship' refers to a set of social rights and responsibilities (with most subsequent attention being given to the former) that are inherent in and emanate from being 'a citizen', that is, a person who is a member of a particular society. ${ }^{4}$ Here, our focus is specifically on Sweden and New Zealand, but citizenship has been a focal point in the international development of social policies. Being a citizen means that a person has rights to access and use a range of social provisions in such key areas as health, education, housing, social assistance and social services. Compulsory education and hospital care are simple examples. In other instances, access results from entitlements established through participation in the labour market and various forms of social insurance. Unemployment and sickness insurance provide useful examples here.

Marshall's implicit argument that social citizenship rights would continue to expand over time, akin to the extension of the franchise (the core element in political rights), 
has been challenged by subsequent scholars and by the experiences of social policy changes of the last two decades (Dwyer, 2004). Two, interconnected, elements of the changes to citizenship are particularly germane to the discussion here. ${ }^{5}$ First, there has been greater emphasis on responsibilities and obligations rather than on rights, highlighting what has been described as 'the republican view of citizenship' (Dwyer, 2004). This emphasis on responsibilities and obligations is manifest in diverse ways around political and social participation, lifestyle, family obligations and, importantly for our purposes, on paid employment as the primary source of income, with the individual being responsible for securing and obtaining employment and/or training that would enhance employment prospects (Andersen et al., 2005; Edwards and Glover, 2001; Lewis and Surender, 2004).

A second and closely linked significant change in the approach to citizenship for this discussion is what has been described as the move from 'passive to active' welfare. Indeed, Hvinden and Johansson (2007) demonstrate that 'active' and 'passive' citizenship can be linked together in quite diverse ways; they are not always discrete. The shift towards 'active citizenship' is inherent in the above discussion, highlighting responsibilities and reducing the emphasis on rights. In brief, 'active citizenship' requires the individual to be 'active' as a citizen and take responsibility for securing the services and accessing the programmes which are required for individual and family well-being. This emphasis stands in contrast to the emphasis on rights, which has increasingly been seen as leading to 'passive' welfare in which the individual and family, it was argued, passively accessed services and programmes as rights (Clark and Maharey, 2001). It should be noted, in passing, that the critique of 'passive' welfare that has developed over the last two decades fails to attend to the ways in which citizenship rights through, for example, means-tested benefits, enabled citizens to be 'active' by providing them with resources to care for themselves and others, including children. In our view, the distinction between 'active' and 'passive' is ideological and political rather than descriptive.

Jensen and Pfau-Effinger (2005) identify four different aspects of active citizenship, namely active citizens as labour-market citizens, as consumers of social security, as parents and caring relatives or friends and as themselves participating in civil society in pursuit of their own interests and by giving to charity (see also Dwyer, 2004). One of the major threads that links the various aspects of active citizenship together is a growing emphasis on individuals as creating and being self-responsible, being 'able to create their biography individually and adapt it continuously to changing external conditions' (Jensen and PfauEffinger, 2005: 7). Importantly, they go on to argue that being responsible for one's own life is, increasingly, an obligation, not an option. The citizen is encouraged, expected (and sometimes required) to take responsibility for himself or herself with the state taking what might be described as a facilitative, supportive or coercive role, or indeed sometimes a mixture of all three components. The nature and analysis of that role will vary depending on the specific actions of local and national public bodies, the immediate political context, political and government ideology and the approach of the commentator.

Active citizenship is a wider concept than the term 'activation' which is used extensively in the social policy and social security literature. The latter, 'activation', refers to specific requirements by governments that recipients of means-tested benefits undertake work and/or activity in order to continue to be eligible to receive assistance. While the particular form of activation differs in different regimes, central to all those different 
forms is a set of requirements related to accepting work offers and/or participating in educational and/or what are euphemistically called 'personal development programmes'. For a useful discussion of different approaches to activation, legally and in practice, see Andersen and Guillemard (2005) and Lødemel and Trickey (2001). The purpose of activation initiatives is to link a recipient into the paid workforce or into activities designed to enhance movement into paid employment. The focus is more specific than that encompassed by the notion of 'active citizenship', which includes those in work as well as those who are not in the paid workforce.

The distinction between active citizenship and activation is neatly captured in Andersen et al.'s (2005) glossary:

Active citizenship: A new ideal of citizenship or a new set of rights and duties based on a conception of a claimant (eg an unemployed person) as an active citizen. The active citizen is granted more autonomy and choice but in return is assumed to be self-responsible, flexible and mobile.

Activation: Job training (in the form of a subsidised temporary job) or education, with the strongly emphasised aim of bringing people back to employment. However, it is sometimes suggested that, in a broader sense, 'activation of social protection' should designate all sorts of restructuring policies that aim to enhance employment. (Andersen et al., 2005: vii)

Active citizenship emphasizes individual responsibilities and obligations rather than social rights. It is, however, focused on the behaviour and circumstances of adults, but with significant implications for children and their lives. It is those implications which now become the focus for our discussion.

\section{Child poverty, children's rights, active citizens, activation}

Policies linked to, based on and arising from active citizenship and activation have both general and specific dimensions, aimed at affecting the lives and behaviour of citizens (adults) but, as already noted, the consequences and outcomes affect children living in poverty. The criteria which determine eligibility for assistance are changed and, at the specific level, these work and income tests lead to greater poverty for children.

At the general level, active citizenship provides support for those in paid work and ensures income adequacy for that group and, generally, the children in those families though a mixture of policies which include the minimum wage and payment of forms of direct tax credits to those who are in paid work. By definition, these payments are not available to those who do not meet the work test requirement. The 'active' citizen is rewarded and encouraged, while the 'passive' citizen is reminded of the value of paid work both by the extra assistance that is available if working and by the low level of benefit being received. An active citizen takes every possible opportunity and makes every possible effort to secure paid work and this work is identified, and regularly reinforced, as the most significant form of income for an individual and his/her family. In this it stands juxtaposed to means-tested payments, which, by definition and by policy action, are inferior and secondary. Implicitly, and sometimes explicitly, those who rely on some form of means-tested assistance are also inferior and secondary, as are their children, an issue to which we return later. As the following discussion demonstrates, this 
support for the active citizen's work efforts is more important than preventing poverty for those who are not in work. 'Preventing poverty' is associated with passive welfare and, arguably, the individual, as an active citizen, should take greater responsibility for actively preventing or alleviating her or his own poverty. Active citizenship represents and reflects significant changes in rights and responsibilities, in the relationship between the state and adult citizens as they relate to one another and as these citizens go about their daily lives. These changes, both politically and in policy directions, have been aimed at shaping the lives and behaviour of adults, with little, if any, attention to what they mean for children in those families which do not meet the active citizen requirements.

Development of and emphasis on the active adult citizen needs to be placed within the context of growing income inequality. The last two decades have seen significant extensions in income inequality throughout most OECD countries and New Zealand and Sweden are no exception to this generalization (OECD, 2008). Indeed, in many respects New Zealand is the example par excellence of growing inequality over that time period, following its economic and social changes in the last two decades. For example, the OECD report shows that between the mid-1980s and mid-2000s, New Zealand's income inequality increased more than any other country (OECD: 2008: 27, Figure 1.2). There has been a small decline in inequality since 2004. Importantly, this coincides with widening of the system of tax credits, a central part of adult active citizenship in relation to employment participation. Some of the explanations for this change in inequality credit the reduction in inequality to the introduction of the tax credits (and associated reforms) in that the changes provided the most significant assistance to those who meet the work test requirement and are not in receipt of government financial assistance (Perry, 2009). In 2008, 28 percent of children were in poverty (using a relative poverty measure and 60 percent of the median income after housing costs). This is the same as the figure a decade earlier (Perry, 2009: 105). The UNICEF report (UNICEF, 2007) which compared poverty figures internationally (using a 50 percent of median income figure) showed New Zealand with a poverty rate just below 15 percent and located between Poland and Portugal. While the data on which this was based preceded Working For Families (WFF), Perry's work suggests that the impact of WFF on poverty rates, using a relative measure of poverty, has been to a significant extent negated by increases in housing costs.

In Sweden, income inequality has gradually grown over the past decades. The highest rate of inequality (counted as a Gini-coefficient) since 1975 was recorded in 2007 and shows especially a gradual distinction between working and non-working families (Statistics Sweden, 2009). Based on fixed prices, the richest tenth increased their disposable incomes by 88 percent between 1991 and 2007 while the poorest tenth ended up with only a 14 percent increase (Statistics Sweden, 2009: 13). Child poverty in Sweden (counted as 60 percent of annual median income) has gradually increased from 8.2 percent to 15.2 percent in the same period (Statistics Sweden, 2009: 29). Child poverty is especially high among lone-parent households and immigrant families.

In an international comparison, child poverty continues to be comparatively low in the Nordic countries. However, the proportion of children in poor households (with an income of less than half the median income of the country) increased more rapidly in Sweden than in the other Nordic countries in the 1990s (UNICEF, 2005). In 17 of a total of 25 rich western counties, including Sweden, child poverty has increased while 
political declarations and goals state the opposite (UNICEF, 2005). From a Swedish perspective, the occurrence of poverty among, primarily, individuals not established in the job market and families with children demonstrates the weaknesses of the Swedish welfare model. A number of reports and studies indicate the same: in the middle of growing, material excess there remains financial vulnerability and the gap between the richer and the poorer households tends to increase (National Board of Health and Welfare, 2006; SOU 2001:79; Statistics Sweden, 2009). Relative poverty means that certain children and their families are prevented from enjoying what is otherwise considered normal or self-evident. In line with the improvement in the economic situations of most families with children, the distance to those remaining in tight financial circumstances increases.

Children's economic vulnerability (counted as low income standard or dependent on means-tested social assistance) increased dramatically in the first half of the 1990s in Sweden and then successively decreased until 2003. The rate has since then been fairly stable, around 12-13 percent on the national level. Children with lone parents and/or parents with foreign background have a distinctly higher risk of living in scarce economic circumstances (Salonen, 2009b). Children in households where the adults experience long-term unemployment are likely to be in a similar position, but not enough is known about their position to be certain about this.

Lessons learned from international comparisons concerning child poverty state that there are no simple links between economic growth and the desirable development of children's conditions. Child poverty is not something unavoidable but reflects how national policies are prioritized as part of social and economic change. The figures reviewed briefly here demonstrate how policy decisions at the general level, linked with growth in inequality, have impacted on child poverty, and, consequentially, have had important effects on children's rights, especially for those children whose parents do not meet the active citizen requirement. We move now to identify specific (targeted) features of some of the general policy changes.

\section{Specific policy initiatives}

At the specific policy level, then, active citizenship policies developed in New Zealand to build, encourage and reward the 'active citizen' included increases in the minimum wage with this moving from NZ\$7.00 to NZ\$12.50 between 1999 and 2009, an argument based on the catchphrase 'making work pay' and, most importantly for our purposes, the range of policy measures introduced in 2004 under the general heading of Working For Families (WFF). WFF extended the In Work Tax Credit (IWTC) introduced in 1996 (as the Independent Family Tax Credit, IFTC) in which a payment of NZ\$15 per child was made to those families which were not dependent on some form of government payment such as a means-tested benefit. WFF strengthened the work test obligation by making receipt of the In Work Payment (IWP) (since renamed the In Work Tax Credit, IWTC) dependent on recipients working a minimum of 30 hours per week for a couple and 20 hours per week for a lone-parent household. The 30 hours per couple can be aggregated in whatever way the couple wishes. ${ }^{6}$

These tax credits represent the most recent component in a movement from universal payments for all children towards a more targeted basis on which to provide financial 
assistance to families with children, the targeting being based on the adults' work participation and/or income. In the New Zealand case this is demonstrated by the 1991 decision to abolish the universal payment for children, known as the Family Benefit, and replace that by extending the targeted form of assistance, known initially as Family Support (FS) and more recently as the Family Tax Credit (FTC). At first, FS was paid for all children whose carer/s met the targeting requirements, but the introduction of the IWTC (initially called the IFTC) in 1996 changed this, differentiating, as noted above, on the basis of whether or not the adult was active, reflected in her/his meeting the work test, and, therefore, qualifying for a higher level of financial assistance on that basis. The abolition of the universal payment, inadequate as that payment was in financially supporting parents caring for dependent children, was linked with the extension of targeted assistance. Increasingly, that targeting has become attached to the behaviour and actions of the adult, not the rights of children, especially those children living in poverty.

In Sweden, the centre-right government, which gained power in 2006, has launched a package of policy reforms that encourage paid work, especially a three-step in-work tax credit and reduction in national income taxes (Swedish Government, 2008). This has reduced taxes substantially for all those who are in paid work. At the same time, this overall policy, with its 'work-first principle', has sharply reduced social security eligibility and contributions, especially for unemployed people. As a consequence, the rate of unemployed people with eligibility for unemployment insurance has dramatically decreased from around 70 percent in 2004 to only 55 percent in 2008 (IAF, 2009). This means that increasing numbers of unemployed people in Sweden, especially young people, lone parents and immigrants, are instead obliged to apply for means-tested social assistance to make ends meet.

In sum, the public discourses on emphasizing paid work in a dual-earner family model in Sweden have sharpened a growing gap in living conditions among children, dependent on parents' position in the labour market. In a child rights perspective this means that children in families with weak positions in the labour market (and therefore reliant on an insecure or insufficient public safety net) are lagging behind economically. The growing inequality gap and increasing poverty among children in both countries has to be understood within a framework of market-driven causes, and in relation to the public policies reflecting and implementing a restricted welfare-to-work discourse.

The evidence from our review of the general policies associated with the movement towards active citizenship suggests that this development, in the context of growing income inequality, weakens the position of the poor and the poorest, extending their obligations and widening already existing income inequalities. In the case of children, their ability to participate and exercise agency is weakened. This ability is one of the hallmarks of the active citizen and is also a central component of children's rights. Moving our attention to the effects of the specific policy measures on child poverty paints a similar picture.

\section{Active adult citizens and poor children}

In New Zealand, a significant number of children live in families and households where the adults do not meet the requirements to be an active citizen. That is, their parents are 
not 'active citizens', at least as that term is applied in relation to means-tested assistance. In 2008, 209,000 children (19.2\%) of New Zealand children were living in a household receiving a means-tested benefit (Perry, 2009). WWF and its predecessor, the IWTC, were clearly focused on rewarding and encouraging adults who demonstrated their active citizenship through their participation in paid work. Both policy initiatives occurred at a time of significant child poverty, emanating from the changes to employment policy, the benefit cuts of 1991 and the changes to housing assistance in the early 1990s. (For those living in public housing, some of the effects of the last of these policy changes were mitigated by changes in housing policy in 2001.)

It was clear from the available research, both within government and outside, that it was children in households receiving government financial assistance who were most at risk of poverty. Maori children, Pacific Islands children, migrant children and those receiving an income support payment (primarily lone parents) were overrepresented in this group. WFF provided assistance for children in poverty if their parents were active citizens. Subsequent analysis clearly demonstrates two major results. The children whose parents meet the work and income test requirements (and therefore qualified because their parents are 'active citizens') were moved out of poverty, leading to a reduction in poverty to levels that are the lowest they have been in 20 years (Perry, 2009). However, for those children whose parents are not 'active', poverty continues and is, arguably, worse. A government report in 2007 talked of 'significant hardship' in these households (Centre for Social Research and Evaluation, 2007). The report found that for beneficiaries with no earned income the median equivalized disposable income fell below 40 percent after housing costs for those with no other income and lay between 45 percent and 48 percent for those with some earned income. Poverty data show some initial reduction in poverty rates following the introduction of WFF, but these rates have increased again, moving back towards levels similar to those which prevailed in 2004 (Perry, 2009).

In addition to the work-tested tax credits, there were also key regulation changes in the 2004 Budget package, with important implications for children in benefit households. The increases to FS which those families received were partly offset by changes in calculation of income in assessing eligibility for benefit. Family Support was now counted as income whereas this had previously not been the case and this, therefore reduced the level of assistance which children and their families could receive. Furthermore, rules surrounding a special supplementary payment for the most impoverished families were changed, reducing the levels of this assistance.

In Sweden, two of the major UNCRC articles, the principle of the best interests of the child as a primary consideration (Article 3) and children's right to express their own views (Article 12), were explicitly implemented in a revision of the Swedish Social Services Act (SoL) 1998. The law states that the child's perspective must be taken into account when adults apply for means-tested social assistance. Yet, in a public revision five years later, it was argued that this explicit child perspective was not implemented consistently in the administration of social assistance (Socialstyrelsen, 2003). One of the major criticisms was a lack of guiding principles on how to interpret and implement an explicit child rights perspective in practice. It was also noted that there was a lack of documentation of whether and in which way children are really heard in these situations. Later studies have underpinned that the child rights perspective in social services is 
symbolic politics rather than a well-established feature of practice (Länsstyrelsen i Stockholms Län, 2005; Rasmusson, 2006). Unanswered questions remain about how the child's interests are interpreted in the administration of poor families with social assistance, for example housing debts, expenses for travelling between biological parents and children's opportunities to participate in leisure activities. Studies indicate a high degree of disparity in discretion when it comes to sanctions towards parents not fulfilling work requirements when applying for social assistance and considering consequences for their children (Salonen and Ulmestig, 2004).

While New Zealand does not have similar legislative provisions as those described above in Sweden, a Children's Agenda was developed in 2002, explicitly stating that it set 'out a programme of action for government, which gives higher priority to their interests, rights and needs' (Maharey et al., 2002: 2). The document noted that government policies would be consistent with the UNCRC and identified child poverty as one of its areas. Within this action area, the document noted that government was 'committed to investing in ways to eliminate child poverty and improve life for individuals, families and communities, both economically and socially' and aimed to end child poverty (Maharey et al., 2002: 21).

Our examination of both the general and the specific policies clearly demonstrates that active citizenship, with its emphasis on the behaviour and lives of adults, leads to policy outcomes which move in opposite and contradictory directions to the emphasis on rights for all children. This is most clearly demonstrated in the child poverty statistics for both New Zealand and Sweden. What would prompt governments to make such decisions, knowing the consequences and knowing the effects on children? In any policy decision, there are choices to be made about focus, design, coverage, implementation and ideological and political 'fit'. In making decisions, governments 'trade off' one set of policy choices and preferences over others. A range of considerations enter into these trade-offs as the general and specific policies join together. The choice here was clearly to pursue directions which were focused on the lives and actions of the adults, while the effects were to be experienced particularly by children living in poverty. ${ }^{7}$ In the mismatch between the two it was reinforcement and encouragement of the adults as active citizens which was to be preferred and, in that context, child poverty is 'traded off' against the preference for policies which encourage and reward participation in paid work. Those children in households which meet the work and income test requirements were fortunate that they could be included in the active citizen adult priority group, but work, not their poverty, was the major policy consideration, as is reflected in the New Zealand government minister's explanation for the policy preference and the trade-off in that country when he said that "the overriding message the government wished to convey in outlining the Working For Families package was the need to provide incentives for families with dependent children to enter and remain in the workforce' (quoted in St John and Craig, 2004: 5).

Despite what was known about child poverty, its incidence, its prevalence and its effects, the policy decision was taken focused on the behaviour of the adults, aiming to encourage them to be active citizens by entering the workforce or by adding to their existing work hours to meet the work test requirement. Promoting and encouraging active citizenship behaviour by adults clearly takes priority over the rights of all children 
to economic security, rights which are reflected in Article 27 of the UNCRC. The empirical evidence clearly shows that the emphasis on active citizenship strengthens obligations and weakens rights for the poorest, particularly for children. To reiterate, active citizenship is aimed at the behaviour of adults, but, at a specific policy level, the results are most heavily experienced by those children living in poverty.

Historically, a distinction has been made between the deserving and undeserving poor as a basis for allocating public resources and deciding on eligibility for assistance, and, commonly, the levels of that assistance. It is a distinction that can be traced back to the Poor Laws and the workhouses of much earlier times. Those distinctions were based on criteria which reflected notions of moral worthiness and culpability, inclusion and exclusion, fault and blame and attributions of personal responsibility for one's poverty (Dean, 1994). The use of work tests and income tests as the passport by which children could be given access to adequate income to ensure that they were no longer in poverty represents the contemporary application of the same principle. Those children whose adult carers are deemed to be 'active citizens' are deserving of assistance which will move them out of poverty. Their peers whose adults do not meet this test are undeserving. As a result, the children who fall into the latter group remain in poverty. They are denied the right to an adequate income and, like their workhouse predecessors, are left to rely on family help or voluntary charity to meet their needs. It is, however, the policies in relation to the adults which determine what happens to the children, not, as was the case in the workhouse, judgements about the moral 'deservingness' of the individual applicant. Policies which identify deserving, active citizens are based on the adult, not the child, but, as noted earlier, the children remain in poverty while their 'deserving' peers receive assistance which takes them out of poverty. Again, the general and the specific policies come together.

Agency has become the subject of growing interest and attention in both the social policy literature and the children's rights literature in the last decade. Being an active agent, exercising maximum autonomy and control over one's own life, is central to the development, ideology, politics and practice of the active citizen. Similarly, through active participation in the issues, decisions and events which affect them, children, it is argued, are and become agents with, increasingly, influence, control and decision-making in relation to their own lives. Children's rights and active citizenship are, then, blended together through the exercise of agency.

At first glance, 'agency' suggests a comfortable degree of fit and significant degree of congruence between children's rights and active citizenship, implying autonomy, control and independence, with 'the agent' possessing, or having access to, the resources, in the widest sense of that term, to exercise that autonomy, control and independence. Governments may express a commitment to and support for children's rights, but the policy choices clearly demonstrate that those rights are unimportant when faced with decisions about policies to support families with children living in poverty. In those decisions, policies aimed at reducing child poverty are traded off for policies which create and support active (adult) citizens. Tax credits enable adults to exercise agency and be active citizens. In order to advance children's rights, all children must be able to exercise agency. This cannot happen when the rights of significant numbers of children to adequate economic security are traded off in favour of requirements that adults should be active citizens. 


\section{Conclusion and implications}

In his discussion of changing citizenship and unemployment, Andersen (2005) argues that one of the central questions for changes in citizenship and the associated policies is whether they extend or reduce existing inequalities and create new social divisions. 'From a citizenship perspective, the two key issues are whether social policies (in actual practice) contribute to equality among citizens and whether they contribute to producing active and efficacious citizens, both in relation to their influence on society and their control over their own situation' (Andersen, 2005: 89). Our cross-country analysis of active citizenship and child rights shows that the trade-off between the two, which prioritizes active citizenship, leaves significant numbers of children in poverty because the two policies are moving in opposite directions, movement in which children bear the consequences.

Exploring this trade-off in other countries will allow testing of the extent to which the trade-off is evident internationally, particularly given the extent to which active citizenship reflects an international trend in social policies. Moreover, it will also allow for a detailed examination of the extent to which the rights of the child have real policy meaning, rather than being, at best, a statement of intent, with full citizenship rights denied to those 'who do not conform to the work ethic' (Lorenz, 2006: 77), with the consequences felt by their children.

\section{Funding}

This research received no specific grant from any funding agency in the public, commercial, or not-for-profit sectors.

\section{Notes}

1. Other Articles such as Articles 6, 24 and 28, which refer to rights to life, to education and to health programmes and services, also have a link to questions of poverty and income adequacy.

2. There is a third section in the book on conceptual issues.

3. The journals concerned were the International Journal of Children's Rights, Children and Society and Childhood.

4. The basis for inclusion and exclusion as a citizen are outside our focus here. They are, of course, critical considerations in the more general debates about citizenship.

5. There are also important changes arising from global migration of peoples and the consequential ethnic and cultural diversity. These are very important issues, but are outside our focus here, although they have important influences on this discussion.

6. The WFF package also included changes to accommodation assistance and childcare provisions, but they are outside our focus here.

7. Of course, the adults in those households are also in poverty.

\section{References}

Andersen J (2005) Citizenship, unemployment and welfare policy. In: Andersen J, Guillemard A, Jensen P and Pfau-Effinger B (eds) The Changing Face of Welfare: Consequences and Outcomes from a Citizenship Perspective. Bristol: The Policy Press.

Andersen J and Guillemard A (2005) Conclusion: Policy change, welfare regimes and active citizenship. In: Andersen J, Guillemard A, Jensen P and Pfau-Effinger B (eds) The Changing Face of Welfare: Consequences and Outcomes from a Citizenship Perspective. Bristol: The Policy Press. 
Andersen J and Jensen P (2002) Citizenship, changing labour markets and welfare policies: an introduction. In: Andersen J and Jensen P (eds) Changing Labour Markets, Welfare Policies and Citizenship. Bristol: The Policy Press.

Andersen J, Guillemard A, Jensen P and Pfau-Effinger B (eds) (2005) The Changing Face of Welfare: Consequences and Outcomes from a Citizenship Perspective. Bristol: The Policy Press.

Belgrave M (2004) Needs and the state: Evolving social policy in New Zealand's history. In: Dalley B and Tennant M (eds) Past Judgement: Social Policy in New Zealand History. Dunedin: University of Otago Press.

Bradshaw J, Hoelscher P and Richardson D (2007) Comparing child well-being in different countries: Concepts and methods. Working Paper 2006-03. UNICEF Innocenti Research Centre, Florence.

Centre for Social Research and Evaluation. (2007) Pockets of significant hardship and poverty. Centre for Social Research and Evaluation, Ministry of Social Development, Wellington.

Cheyne C, O'Brien M and Belgrave M (2008) Social Policy in Aotearoa New Zealand: A Critical Introduction. Auckland: Oxford University Press.

Clark H and Maharey S (2001) Pathways to opportunity: Nga Ara Whai Oranga. From social welfare to social development. Ministry of Social Development, Wellington.

Clutton S (2008) Devolution and the language of children's rights in the UK. In: Invernizzi A and Williams J (eds) Children and Citizenship. London: Sage.

Dean M (1994) The Constitution of Poverty: Towards a Genealogy of Liberal Governance. London: Routledge.

Dwyer P (2004) Understanding Social Citizenship: Themes and Perspectives for Policy and Practice. Bristol: The Policy Press.

Edwards R and Glover J (eds) (2001) Risk and Citizenship: Key Issues in Welfare. London: Routledge.

Hallett C and Prout A (eds) (2003) Hearing the Voices of Children: Social Policy for a New Century. London: RoutledgeFalmer.

Howe R and Covell K (2003) Child poverty in Canada and the rights of the child. Human Rights Quarterly 25(4): 1067-1087.

Hvinden B and Johansson H (eds) (2007) Citizenship in Nordic Welfare States. Abingdon: Routledge.

IAF (Inspektionen för arbetslöshetsförsäkringen). (2009) Arbetssökande med och utan arbetslöshetsförsäkring [Unemployed with and without unemployment insurance]. Rapport 2009:7. Katrineholm.

Invernizzi A and Williams J (eds) (2008) Children and Citizenship. London: Sage.

James A, Jenks C and Prout A (1998) Theorizing Childhood. Cambridge: Polity Press.

Jensen P and Pfau-Effinger B (2005) 'Active' citizenship: The new face of welfare. In: Andersen J, Guillemard A, Jensen P and Pfau-Effinger B (eds) The Changing Face of Welfare: Consequences and Outcomes from a Citizenship Perspective. Bristol: The Policy Press.

Johansson H and Hornemann Möller I (eds) (2009) Aktivering - Arbetsmarknadspolitik och socialt arbete i förändring [Activation - Labour market policies and social work in transition]. Malmö: Liber Förlag.

Länsstyrelsen i Stockholms Län. (2005) Barnperspektiv vid långvarigt socialbidragsberoende [Child perspective in families with long-term social assistance]. Stockholm.

Lewis J and Surender R (eds) (2004) Welfare State Change: Towards A Third Way? Oxford: Oxford University Press.

Lister R (1997) Citizenship: Feminist Perspectives. Basingstoke: Macmillan.

Lister R (2003) Investing in the citizen-workers of the future: Transformation in citizenship and the state under New Labour. Social Policy and Administration 37(5): 427-443. 
Lister R (2004a) Ending child poverty: A matter of human rights, citizenship and social justice. In: Doran P (ed.) Ending Child Poverty in 2020: The First Five Years. London: Child Poverty Action Group.

Lister R (2004b) The Third Way's social investment state. In: Lewis J and Surender R (eds) Welfare State Change: Towards a Third Way? Oxford: Oxford University Press.

Lister R (2007a) Inclusive citizenship: Realizing the potential. Citizenship Studies 11(1): 49-61.

Lister R (2007b) Why citizenship: Where, when and how children? Theoretical Inquiries in Law 8(2): 693-718.

Lødemel I and Trickey H (eds) (2001) 'An Offer You Can't Refuse': Workfare in International Perspective. Bristol: The Policy Press.

Lorenz W (2006) Perspectives on European Social Work. Leverkusen: Barbara Budrich Publishers.

Maharey S, Harre L and Turia T (2002) New Zealand's agenda for children. Ministry of Social Development, Wellington.

Mayall B (2002) Towards a Sociology of Childhood: Thinking from Children's Lives. Milton Keynes: Open University Press.

National Board of Health and Welfare. (2006) Social rapport 2006 [Social report 2006]. Stockholm.

O'Brien M (2008) Poverty, Policy and the State: Social Security Reform in New Zealand. Bristol: The Policy Press.

OECD (Organization for Economic Cooperation and Development). (2008) Growing Unequal? Paris: OECD.

Oliver M and Barnes M (1998) Disabled People and Social Policy: From Exclusion to Inclusion. London: Longman.

Pardeck J (2006) Children's Rights: Policy and Practice. New York: Haworth Social Work Practice Press.

Perry B (2009) Household incomes in New Zealand: Trends in indicators of inequality and hardship 1982 to 2008. Ministry of Social Development, Wellington.

Prout A (2000) Children's participation: Control and self-realisation in British late modernity. Children and Society 14(4): 304-315.

Qvortrup J (ed.) (2005) Studies in Modern Childhood: Society, Agency, Culture. Basingstoke: Palgrave Macmillan.

Rasmusson B (2006) Barnperspektiv i den sociala barnavården [Child perspective in child welfare services]. Meddelanden från Socialhögskolan Lund 2006:2.

Ridge T (2006) Childhood poverty: A barrier to social participation. In: Tisdall E, Davis J, Hill M and Prout A (eds) Children, Young People and Social Participation: Participation for What? Bristol: The Policy Press, 23-28.

Salonen T (2009a) Sweden: Between model and reality. In: Alcock P and Craig G(eds) International Social Policy, Welfare Regimes in the Developed World. Basingstoke: Palgrave Macmillan.

Salonen T (2009b) Barns ekonomiska utsatthet - Arsrapport 2008 [Children in poor families Annual report 2008]. Stockholm: Rädda Barnen.

Salonen T and Ulmestig R 2004 Nedersta trappsteget. En studie i kommunal aktivering [The lowest step: A study on local activation]. Rapportserie i socialt arbete No. 1. Institutionen för socialt arbete och vårdvetenskap, Växjö universitet.

Socialstyrelsen. (2003) Barnperspektiv vid handläggning av ekonomiskt bistånd [Child perspective in management of social assistance]. National Board of Health and Welfare, Stockholm.

SOU 2001:79. Välfärdsbokslut för 1990-talet [Balance sheet of welfare in the 1990s]. Slutbetänkande från kommittén välfärdsbokslut. Ministry of Health and Social Affairs, Stockholm.

St John S and Craig D (2004) Cut price kids: Does the 2004 'Working for Families' Budget work for children? Child Poverty Action Group, Auckland. 
Statistics Sweden. (2009) Inkomstfördelningsundersökningen 2007 [Income distribution survey 2007]. HE 21 SM 0901. Stockholm.

Swedish Government. (2008) The Swedish Reform Programme for Growth and Jobs 2008 to 2010. Available at: www.regeringen.se.

Tisdall E (ed.) (2006) Children, Young People and Social Inclusion; Participation for What? Bristol: The Policy Press.

Ulmestig R (2007) På gränsen till fattigvård? En studie om arbetsmarknadspolitik och socialbidrag [On the boundaries of poor relief? A study of labour market policy and social assistance]. Dissertations in Social Work No. 27. School of Social Work, Lund.

UNICEF. (2005) Child poverty in rich countries 2005. Innocenti Research Centre Report Card No. 6. Florence.

UNICEF. (2007) An overview of child well-being in rich countries. Innocenti Research Centre Report Card No. 7. Florence.

Van Bueren G (1999) Combating child poverty: Human rights approaches. Human Rights Quarterly 21(3): 680-706. 